\title{
Viral encephalopathy and retinopathy outbreak in freshwater fish farmed in Italy
}

\author{
G. Bovo ${ }^{1}$, A. Gustinelli ${ }^{2}$, F. Quaglio ${ }^{3}$, F. Gobbo ${ }^{1}$, V. Panzarin ${ }^{1}$, A. Fusaro¹, \\ F. Mutinelli ${ }^{1}$, M. Caffara ${ }^{2}$, M. L. Fioravanti ${ }^{2, *}$
}

\begin{abstract}
${ }^{1}$ Istituto Zooprofilattico Sperimentale delle Venezie, OIE Reference Laboratory for Viral Encephalopathy and Retinopathy, 35020 Legnaro (PD), Italy
\end{abstract}

${ }^{2}$ Department of Veterinary Medical Sciences, Alma Mater Studiorum Università di Bologna, 40064 Ozzano Emilia (BO), Italy

${ }^{3}$ Department of Public Health, Comparative Pathology and Veterinary Hygiene, University of Padua, 35020 Legnaro (PD), Italy

\begin{abstract}
Viral encephalopathy and retinopathy (VER), otherwise known as viral nervous necrosis (VNN), is a neuropathological condition affecting $>40$ species of fish. Although VER affects mainly marine fish, the disease has also been detected in certain species reared in freshwater environments. There are relatively few reports concerning the disease in freshwater species, and there is not much information on clinical signs. Nevertheless, the most common clinical findings reported from affected freshwater species are consistent with the typical signs observed in marine species. In this paper we describe the main clinical signs and the laboratory results associated with the detection of a betanodavirus in hybrid striped bass $\times$ white bass (Morone saxatilis $\times$ Morone chrysops) and largemouth bass Micropterus salmoides, reared in a freshwater environment. We also detected the virus by realtime PCR and isolated it in cell culture from a batch of pike-perch Sander lucioperca farmed in the same system.
\end{abstract}

KEY WORDS: VER · Hybrid striped bass $\cdot$ Morone saxatilis $\times$ Morone chrysops $\cdot$ Largemouth bass Micropterus salmoides $\cdot$ Freshwater environment $\cdot$ Molecular characterization

Resale or republication not permitted without written consent of the publisher

\section{INTRODUCTION}

Viral encephalopathy and retinopathy (VER) (Munday et al. 1992, OIE 2006), otherwise known as viral nervous necrosis (VNN) (Yoshikoshi \& Inoue 1990), is a neuropathological condition affecting $>40$ species of fish (Maltese \& Bovo 2007). The disease is caused by small, icosahedral RNA viruses belonging to the family Nodaviridae (Schneemann et al. 2005). Based on phylogenetic analysis of the T4 variable region of the capsid gene, piscine nodaviruses have been classified into 4 major genotypes (Nishizawa et al. 1997), namely, Red spotted grouper nervous necrosis virus (RGNNV), Barfin flounder nervous necrosis virus (BFNNV), Striped jack nervous necrosis virus (SJNNV) and Tiger puffer nervous necrosis virus (TPNNV). The existence of an additional genotype, including the turbot nodavirus (TNV) has been proposed more recently (Johansen et al. 2004).
Despite affecting mainly marine fish, VER has also been detected in certain freshwater species, such as tandan fish Tandanus tandanus and sleepy cod Oxyeleotris lineolatus (Munday et al. 2002), European eel Anguilla anguilla (Chi et al. 2003), guppy Poecilia reticulata (Hegde et al. 2003), Amur catfish Parasilurus asotus (Chi et al. 2003), Danube sturgeon Acipenser gueldenstaedtii (Athanassopoulou et al. 2004) and Nile tilapia Oreochromis niloticus (Bigarré et al. 2009). The disease has also been experimentally induced in Mozambique tilapia Oreochromis mossambicus (Skliris \& Richards 1999). These observations suggest that salinity is not a limiting factor and raise concerns about the possibility that the disease may spread to economically important freshwater species following accidental exposure to the causative agent. The high homology observed between the viral isolate obtained from the saltwater species Epinephelus taurina - Epinephelus taurina nervous necrosis virus (ETNNV) - and the viral isolate obtained from 
the common ornamental freshwater fish Poecilia reticulata (Guppy nervous necrosis virus; GNNV) (Hegde et al. 2003) suggests a potential marine origin for the infection detected in this freshwater species. Very few reports exist on the disease in freshwater species. The abnormal swimming behaviour - which is the most consistent finding observed in marine species - has also been reported in affected freshwater species, suggesting that the same pathogenic mechanisms may affect fish in both marine and freshwater environments.

In this study, we investigated the occurrence of betanodavirus infection in hybrid striped bass $\times$ white bass (Morone saxatilis $\times$ Morone chrysops), largemouth bass Micropterus salmoides and pike-perch Sander lucioperca reared in a freshwater farm located in northern Italy.

\section{MATERIALS AND METHODS}

Case history. In June 2009, a batch of 200000 hybrid striped bass ( $M$. saxatilis $\times M$. chrysops) - aged $30 \mathrm{~d}$, and weighing 0.1 to $0.2 \mathrm{~g}$ - was imported from Israel and introduced into a freshwater farm located in northern Italy. On arrival, the larvae were stocked in tanks supplied with fresh water originating from the Po River catchment basin.

One week after their introduction, the first clinical sign - abnormal swimming behaviour - appeared in a few fish; these fish subsequently died. The fish continued to die over a period of $15 \mathrm{~d}$, reaching a cumulative value of $20 \%$ of the initial batch by the end of the outbreak. At the peak of fish mortality the water temperature was 28 to $30^{\circ} \mathrm{C}$.

About $30 \mathrm{~d}$ after the first outbreak, similar signs were observed among 2 different species of fish in different sectors of the farm; this outbreak was associated with a lower mortality than that observed in the hybrid striped bass. In particular, mortality was observed among a batch of 300000 largemouth bass Micropterus salmoides - hatched on-site, and aged 15 to $20 \mathrm{~d}$ - as well as among pike-perch Sander lucioperca, aged $60 \mathrm{~d}$, from a batch of 20000 fish introduced from eastern Europe in June 2009.
Sampling. The first sampling, consisting of largemouth bass fry, was performed in July 2009 directly by the farmer worried by the increased mortality and the uncommon clinical signs. In addition to standard diagnostic procedures, the unusual clinical signs encouraged the authors to perform further procedures for the specific detection of betanodaviruses.

Table 1 shows the overall sampling scheme carried out on the farm. Further detailed data on samples and hosts are given in Table 3 .

Virus isolation. Whole heads, or individual brains and eyes, were homogenized in a mortar with sterile sand and diluted 1:10 in Eagle's minimum essential medium (E-MEM) containing 5\% fetal bovine serum. Homogenized tissues were centrifuged for $15 \mathrm{~min}$ at $4000 \times g$ at $4^{\circ} \mathrm{C}$. An antibiotic-antimycotic solution $(10 \% \mathrm{v} / \mathrm{v})$ (Sigma-Aldrich ${ }^{\circledR}$, A5955) and kanamycin sulphate solution $(0.4 \%)$ (Sigma-Aldrich ${ }^{\circledR}$, K0254) were added to the supernatants which were then stored at $4^{\circ} \mathrm{C}$ overnight. The following day, $100 \mu \mathrm{l}$ of each sample were inoculated onto $24 \mathrm{~h} \mathrm{SSN-1}$ cell monolayers growing in 24-well plates, at 2 final dilutions corresponding to $1: 100$ and 1:1000. After inoculation, the cell cultures were incubated at $25 \pm 2{ }^{\circ} \mathrm{C}$ for $10 \mathrm{~d}$ and regularly inspected for cytopathic effects (cpe).

If no cpe appeared by $10 \mathrm{~d}$ post-inoculation, a blind virus subcultivation was initiated on new SSN-1 monolayers. Cell cultures were monitored for a further $10 \mathrm{~d}$. Samples were considered negative if no cpe appeared following the subcultivation period.

Histology and immunohistochemistry (IHC). Moribund largemouth bass and hybrid striped bass were euthanized and fixed in $10 \%$ buffered formalin, dehydrated through a graded ethanol-xylene series, and embedded in paraffin. Sagittal sections, $5 \mu \mathrm{m}$ thick, were stained with haematoxylin and eosin (H\&E).

Parallel sections including the whole fish were subjected to IHC procedures for detection of betanodavirus antigens (Mutinelli et al. 1998). Briefly, paraffin sections were trypsinized at $37^{\circ} \mathrm{C}$ for $30 \mathrm{~min}$, pre-incubated with normal horse serum for $20 \mathrm{~min}$, and incubated with a rabbit polyclonal hyperimmune serum (anti-VER-238) diluted 1:2000 for $30 \mathrm{~min}$. After incuba-

Table 1. Affected species, origin, sampling dates, and age

\begin{tabular}{|lccrc|}
\hline Affected species & Introduction into the farm & Sampling date & Clinical signs & Age (d) \\
\hline Micropterus salmoides & Hatched on-site & July 62009 & Yes & 20 \\
Morone saxatilis $\times$ Morone chrysops & June 2009 & July 6 2009 & Yes & 65 \\
Sander lucioperca & June 2009 & July 16 2009 & Yes & 60 \\
Micropterus salmoides & Hatched on-site & July 16 2009 & Yes \\
Micropterus salmoides & Hatched on-site & July 16 2009 & Yes \\
Morone saxatilis $\times$ Morone chrysops & June 2009 & September 25 2009 & Yes \\
Micropterus salmoides & Hatched on-site & September 25 2009 & Yes & 90 \\
& & & & 91 \\
\hline
\end{tabular}


tion with 'universal' biotinylated secondary antibody, we used R.T.U. Vectastain ${ }^{\circledR}$ Universal Elite ${ }^{\circledR}$ ABC KIT (PK-7200) as the detection system for $30 \mathrm{~min}$ and 3amino-9-ethylcarbazole as chromogen. Sections were counterstained with Mayer's haematoxylin. Appropriate positive and negative controls were included. The samples were observed at different magnifications with a Zeiss microscope (Axioscope).

Real-time PCR. Homogenized tissues were processed by real-time PCR according to Panzarin et al. (2010). Briefly, total RNA was extracted from $100 \mu$ l of sample using the NucleoSpin ${ }^{\circledR}$ RNA II kit (MachereyNagel) according to the manufacturer's instructions. After cDNA synthesis with the High Capacity cDNA Reverse Transcription Kit (Applied Biosystems), realtime PCR was conducted with the LightCycler 2.0 system using the LightCycler ${ }^{\circledR}$ TaqMan ${ }^{\circledR}$ Master (Roche Diagnostics) following the manufacturer's recommendations. Primers and probe (Table 2) were used at a final concentration of $0.9 \mu \mathrm{M}$ and $0.75 \mu \mathrm{M}$, respectively, and thermal cycling was performed at $95^{\circ} \mathrm{C}$ for 10 min followed by 45 cycles of $95^{\circ} \mathrm{C}$ for $10 \mathrm{~s}, 58^{\circ} \mathrm{C}$ for $35 \mathrm{~s}$ and $72^{\circ} \mathrm{C}$ for $1 \mathrm{~s}$, with a final incubation at $40^{\circ} \mathrm{C}$ for $30 \mathrm{~s}$. Data analyses were performed with the LightCycler software 4.

Reverse transcriptase PCR (RT-PCR), sequencing and phylogenetic analysis. Total RNA, extracted as above from positive cell culture supernatants, was subjected to reverse transcription followed by PCR amplification using the OneStep RT-PCR kit (Qiagen) according to the manufacturer's instructions. Primers were used at a final concentration of $0.2 \mathrm{mM}$. The VNNV1-VNNV2 set targeted a variable region within the viral RNA2 segment, while the VNNV5-VNNV8 and FOR 521-VNNV6 sets amplified overlapping regions within the viral RNA1 molecule (Table 2). The thermocycling conditions were: $50^{\circ} \mathrm{C}$ for $30 \mathrm{~min}, 95^{\circ} \mathrm{C}$ for 15 min and 40 cycles of $30 \mathrm{~s}$ denaturation at $94^{\circ} \mathrm{C}_{\text {, }}$ $30 \mathrm{~s}$ annealing at $60^{\circ} \mathrm{C}$ and $45 \mathrm{~s}$ elongation at $72^{\circ} \mathrm{C}$; the reaction was terminated with a 10 min elongation at $72^{\circ} \mathrm{C}$. PCR products were analyzed for purity and size by electrophoresis in $2 \%$ agarose gel after staining with GelRed ${ }^{\mathrm{TM}}$ Nucleic Acid Gel Stain (Biotium) and subsequently purified with ExoSAP-IT ${ }^{\circledR}$ (USB) following the manufacturer's recommendations. Amplicons were sequenced in both directions with the same primers adopted for RT-PCR using the Big Dye Terminator v3.1 cycle sequencing kit (Applied Biosystems). The products were cleaned-up using the PERFORMA ${ }^{\circledR}$ DTR Ultra 96-Well Plate kit (Edge BioSystems) and sequenced in a 16-capillary ABI PRISM ${ }^{\circledR}$ 3130xl Genetic Analyzer (Applied Biosystems). Sequence data were assembled and edited with SeqScape ${ }^{\circledR}$ software v2.5 (Applied Biosystems). The RNA1 and RNA2 partial sequences were aligned and compared to the corresponding regions of representative betanodavirus strains publicly available in GenBank (http://www.ncbi.nlm.nih.gov) using MEGA 4 software (Tamura et al. 2007). Phylogenetic trees were developed using the neighbour-joining (NJ) method with 1000 bootstrap resamplings. Nucleotide similarities between betanodavirus isolates were determined.

\section{RESULTS}

\section{Virus isolation}

Typical cpe, consisting of intracytoplasmic vacuoles, appeared 3 to $4 \mathrm{~d}$ after inoculation of the homogenate tissues in SSN-1. In the following days the cpe developed further, affecting most of the cells - which finally detached from the substrate. No cpe were observed in negative controls. Viruses were isolated from fish

Table 2. Oligonucleotides used for real-time TaqMan PCR, reverse transcriptase PCR (RT-PCR) and sequence reaction protocols. Sequences of the oligos $(5 \rightarrow 3)$, product size and nucleotide position are shown

\begin{tabular}{|c|c|c|c|c|}
\hline Primer/probe & Sequence $(5 \rightarrow 3)$ & $\begin{array}{l}\text { Amplicon } \\
\text { size (bp) }\end{array}$ & $\begin{array}{l}\text { Nucleotide } \\
\text { position }\end{array}$ & Source \\
\hline RNA2 FOR ${ }^{a}$ & CAA CTG ACA RCG AHC ACA C & \multirow[t]{3}{*}{69} & $392 \rightarrow 410$ & Panzarin et al. (2010) \\
\hline RNA2 REV ${ }^{\mathrm{a}}$ & CCC ACC AYT TGG CVA C & & $460 \rightarrow 445$ & Panzarin et al. (2010) \\
\hline RNA2 Probe ${ }^{a}$ & 6FAM-TYC ARG CRA CTC GTG GTG CVG-BHQ1 & & $422 \rightarrow 442$ & Panzarin et al. (2010) \\
\hline VNNV1 ${ }^{b}$ & ACA CTG GAG TTT GAA ATT CA & \multirow[t]{2}{*}{605} & $158 \rightarrow 177$ & Toffolo et al. (2007) \\
\hline $\mathrm{VNNV}^{\mathrm{b}}$ & GTC TTG TTG AAG TTG TCC CA & & $762 \rightarrow 743$ & Toffolo et al. (2007) \\
\hline VNNV5 $^{\mathrm{c}}$ & GTT GAG GAT TAT CGC CAA CG & \multirow[t]{2}{*}{478} & $178 \rightarrow 197$ & Toffolo et al. (2007) \\
\hline VNNV8 ${ }^{c}$ & CAG CAA CAC GGT AGT G & & $655 \rightarrow 640$ & Toffolo et al. (2007) \\
\hline FOR $521^{\mathrm{c}}$ & ACG TGG ACA TGC ATG AGT TG & \multirow[t]{2}{*}{630} & $521 \rightarrow 540$ & Present study \\
\hline VNNV6 ${ }^{\mathrm{c}}$ & ACC GGC GAA CAG TAT CTG AC & & $1150 \rightarrow 1131$ & Toffolo et al. (2007) \\
\hline
\end{tabular}


showing clinical signs among all 3 species reared on the farm (Table 3). In fish collected in September3 mo after the appearance of the disease - the virus was detected in 2 of 10 asymptomatic hybrid striped bass, processed individually.

\section{Histology and immunohistochemistry (IHC)}

Histopathological observation of samples obtained from largemouth bass Micropterus salmoides and pike-perch Sander lucioperca revealed lesions in the eye, brain, spinal cord and ganglia of the peripheral nervous system. Almost all the fish we examined had degenerative and vacuolated ocular lesions in the retina (Fig. 1a,b). Vacuoles were present in the nuclear layers of the retina, especially within the bipolar layer. Occasionally the pigmented layer was also affected. The grey matter of the brain showed pathological changes primarily in the olfactory lobe (telencephalon) and in the optic tectum (mesencephalon) (Fig. 1c,d). These included spongious changes characterized by cytoplasmic vacuolation and focal necrosis with nuclear pyknosis and karyorrhexis. In some cases, severe congestion of the meningeal blood vessels was observed. Perivascular gliosis was sometimes found. A focal extensive haemorrhage within the third ventricle, associated with swelling, was observed in 1 sample of largemouth bass. Spongiform degenerations of neurons in the spinal cord and peripheral nerves were noted (Fig. 1e,f). The severity varied from focal to diffuse multifocal vacuolations.

Positive staining for nervous necrosis virus antigen was observed in both retina and brain tissues. In the retina, severe vacuolation associated with deposition of a brown-reddish product was detected mainly in the outer nuclear layer and within the bipolar layer (Fig. 1b). In the grey matter of the brain, similar positive staining was located mainly in neurons and associated spongiotic tissue. The viral antigen was not detected in the other organs examined.

\section{Real-time PCR}

Betanodavirus was detected in all the fish species investigated; 18 out of 24 samples tested positive by the molecular test, and 12 of the 18 were also con-

Table 3. Analytical results obtained during the outbreak of viral encephalopathy and retinopathy (VER) in largemouth bass Micropterus salmoides, pike-perch Sander lucioperca and hybrid bass (Morone saxatilis $\times$ Morone chrysops). For each sample, the laboratory code and the host are reported. RGNNV: Red spotted grouper nervous necrosis virus. +: a positive result, -: a negative result. IHC: immunohistochemistry. np: not performed. CP (crossing point) values are reported for samples testing positive in the real-time PCR

\begin{tabular}{|c|c|c|c|c|c|c|}
\hline \multirow{2}{*}{ Lab code } & \multirow[t]{2}{*}{ Host } & \multirow[b]{2}{*}{ Virus isolation } & \multirow[b]{2}{*}{ Histology } & \multicolumn{2}{|c|}{ - Analytical results } & \multirow[b]{2}{*}{ Genotype } \\
\hline & & & & $\mathrm{IHC}$ & Real-time PCR (CP) & \\
\hline $243 / 1^{a}$ & M. salmoides & + & + & + & $+(11.63)$ & RGNNV \\
\hline $243 / 2^{\mathrm{a}}$ & M. saxatilis $\times$ M. chrysops & - & + & + & $+(34.50)$ & np \\
\hline $243 / 3^{a}$ & M. saxatilis $\times$ M. chrysops & + & + & + & $+(12.31)$ & RGNNV \\
\hline $265^{\mathrm{a}}$ & S. lucioperca & + & $\mathrm{np}$ & np & $+(17.84)$ & RGNNV \\
\hline $266 / 1^{\mathrm{a}}$ & M. salmoides & + & + & + & $+(7.91)$ & RGNNV \\
\hline $266 / 2^{\mathrm{a}}$ & M. salmoides & + & + & + & $+(8.50)$ & RGNNV \\
\hline $266 / 3^{a}$ & M. salmoides & + & + & + & $+(7.93)$ & RGNNV \\
\hline $266 / 4^{\mathrm{a}}$ & M. salmoides & + & $\mathrm{np}$ & np & $+(6.62)$ & RGNNV \\
\hline $266 / 5^{\mathrm{a}}$ & M. salmoides & + & $\mathrm{np}$ & np & $+(6.80)$ & RGNNV \\
\hline $336 / 1$ & M. saxatilis $\times$ M. chrysops & + & - & - & $+(26.19)$ & RGNNV \\
\hline $336 / 2$ & M. saxatilis $\times M$. chrysops & - & - & - & $+(22.87)$ & $\mathrm{np}$ \\
\hline $336 / 3$ & M. saxatilis $\times$ M. chrysops & - & - & - & $+(21.54)$ & np \\
\hline $336 / 4$ & M. saxatilis $\times$ M. chrysops & + & - & - & $+(21.12)$ & RGNNV \\
\hline $336 / 5$ & M. saxatilis $\times$ M. chrysops & - & - & + & $+(20.62)$ & $\mathrm{np}$ \\
\hline $336 / 6$ & M. saxatilis $\times$ M. chrysops & - & - & - & $+(28.53)$ & $\mathrm{np}$ \\
\hline $336 / 7$ & M. saxatilis $\times M$. chrysops & - & - & - & - & $\mathrm{np}$ \\
\hline $336 / 8$ & M. saxatilis $\times M$. chrysops & - & - & - & $+(26.65)$ & $\mathrm{np}$ \\
\hline $336 / 9$ & M. saxatilis $\times M$. chrysops & - & - & - & - & $\mathrm{np}$ \\
\hline $336 / 10$ & M. saxatilis $\times M$. chrysops & - & - & - & - & $\mathrm{np}$ \\
\hline $337^{\mathrm{a}}$ & M. salmoides & + & np & np & $+(20.62)$ & RGNNV \\
\hline 338 & M. salmoides & + & np & np & $+(15.27)$ & RGNNV \\
\hline 339 & M. saxatilis $\times$ M. chrysops & - & - & - & - & $\mathrm{np}$ \\
\hline 340 & M. saxatilis $\times M$. chrysops & - & - & - & - & np \\
\hline 341 & M. saxatilis $\times$ M. chrysops & - & - & - & - & $\mathrm{np}$ \\
\hline
\end{tabular}



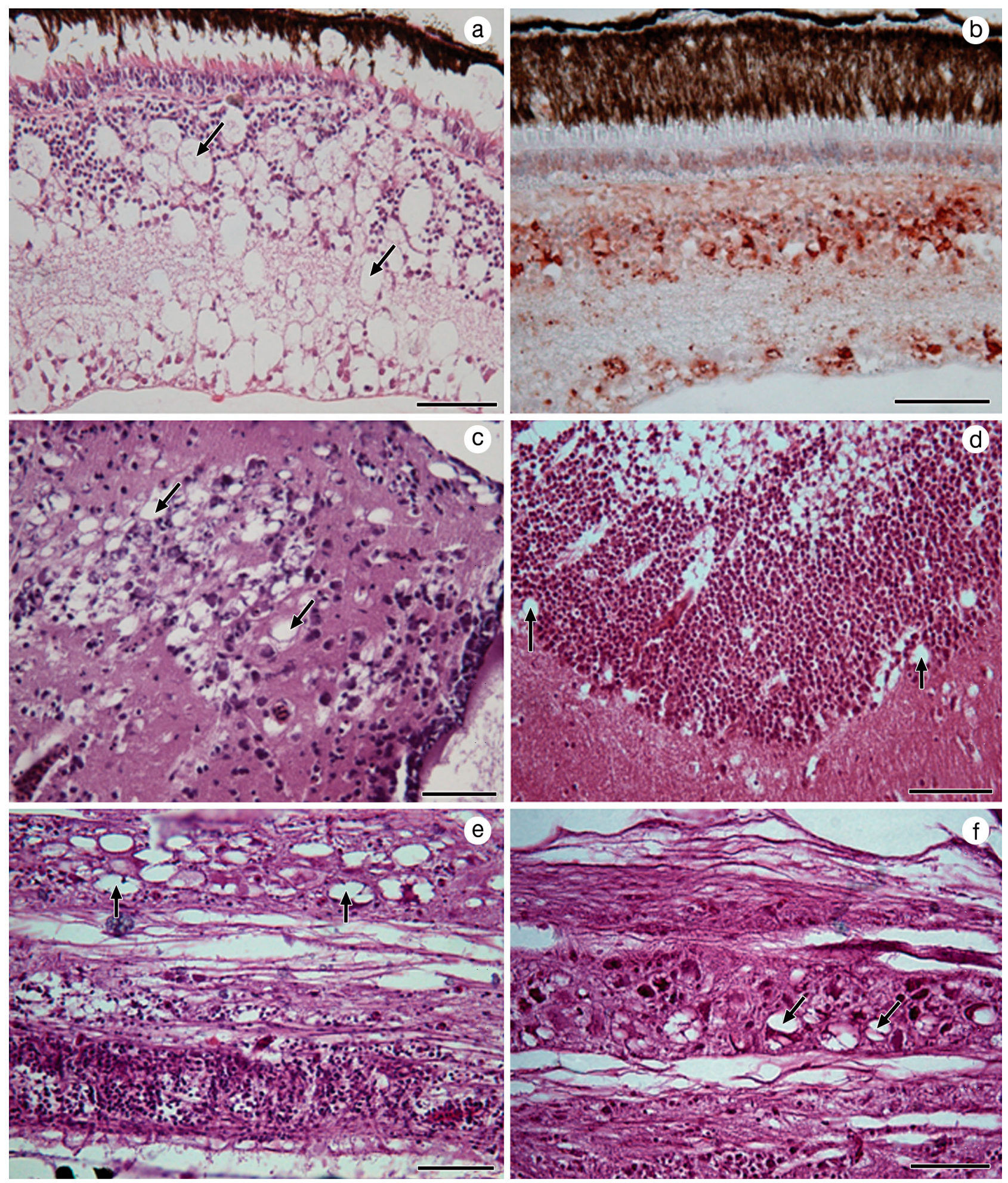

Fig. 1. Hybrid striped bass (Morone saxatalis $\times$ M. chrysops) and largemouth bass Micropterus salmoides. (a,b) Cross section of retina. (a) Hybrid striped bass; vacuolar lesions are marked (arrows) in the outer and inner nuclear layers (H\&E); (b) Largemouth bass; positive nodavirus antigens in the nuclear layer of retina (immunohistochemistry). (c,d) Cross section of brain (H\&E). (c) Hybrid striped bass; vacuolation (arrows), necrosis with pyknosis and karyorrhexis in the olfactory lobe of brain; (d) Largemouth bass; vacuolar lesions (arrows) in the granular layer of mesencephalon. (e,f) Sagittal section showing vacuolar lesions (arrows) in neurons of spinal cord (H\&E). (e) Hybrid striped bass; (f) Largemouth bass. Scale bars $=50 \mu \mathrm{m}$ 
firmed positive by virological analysis. Detailed analytical results obtained from the real-time PCR are reported in Table 3.

\section{Phylogenetic characterization}

Phylogenetic analysis of both the viral RNA1 and RNA2 segments revealed that all the isolates obtained from the 3 species of fish affected during the same outbreak of VER fell within the RGNNV genogroup
(Table 3), forming well defined clusters supported by high bootstrap values (Figs. 2 \& 3). The RNA1 nucleotide sequences of the newly isolated strains were almost identical (99.9\% similar) and were closely related to strain LcNNV 09/07 (nucleotide similarity ranged from 97.8 to $97.9 \%$ ). Pair-wise distance calculated for the RNA2 segment showed $99.8 \%$ similarity among the freshwater betanodaviruses characterized in this study, which possessed the highest identity (98.4 to $98.7 \%$ ) to the RGNNV strain related to accession number AY744705.

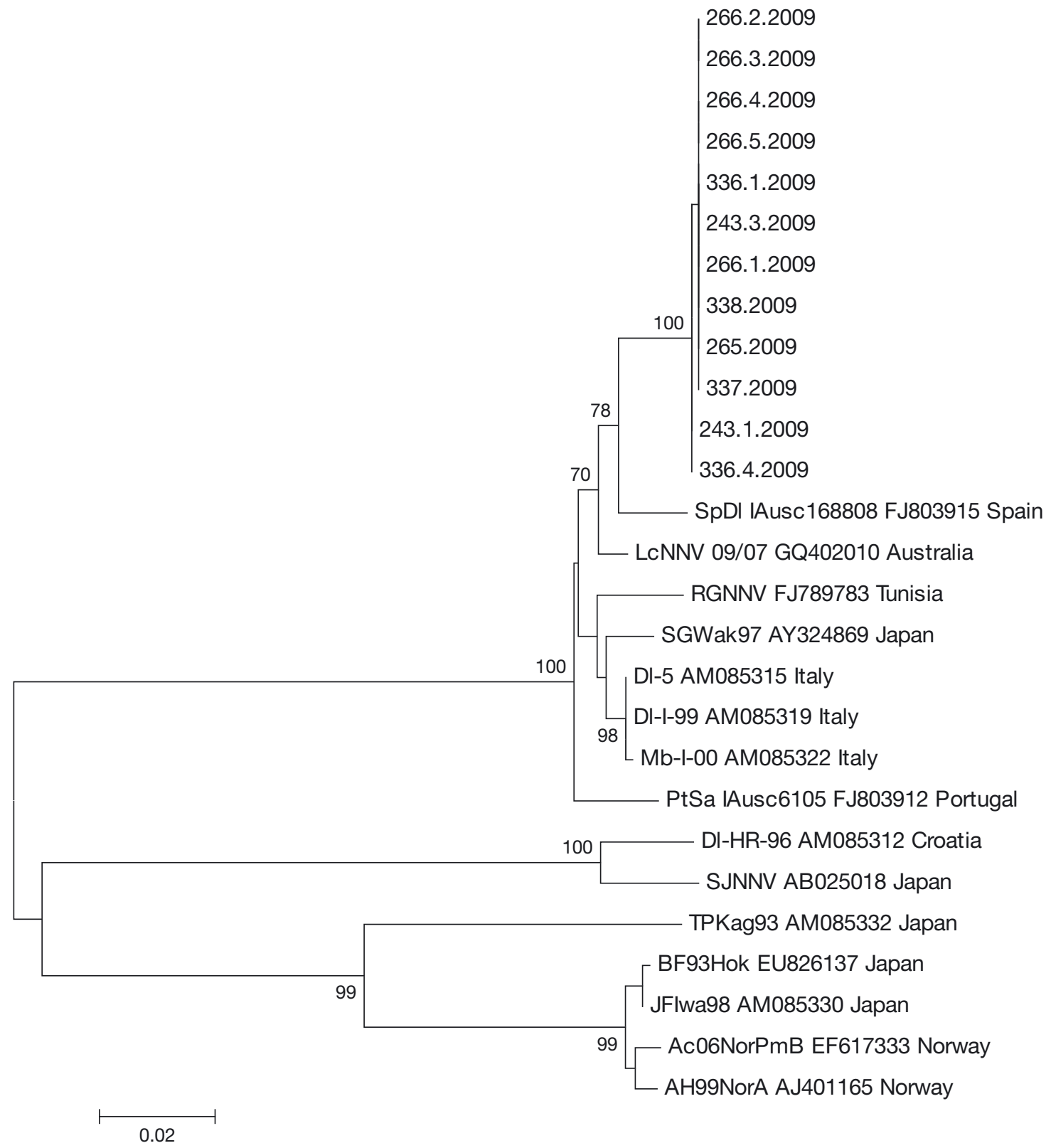

Fig. 2. Neighbour-joining (NJ) phylogenetic tree based on 870 bp nucleotide sequences of the RNA1 segment. Nodes are labelled with bootstrap values expressed as percentages. Only values $\geq 70$ are reported. The scale bar represents 0.02 nucleotide substitution per site 


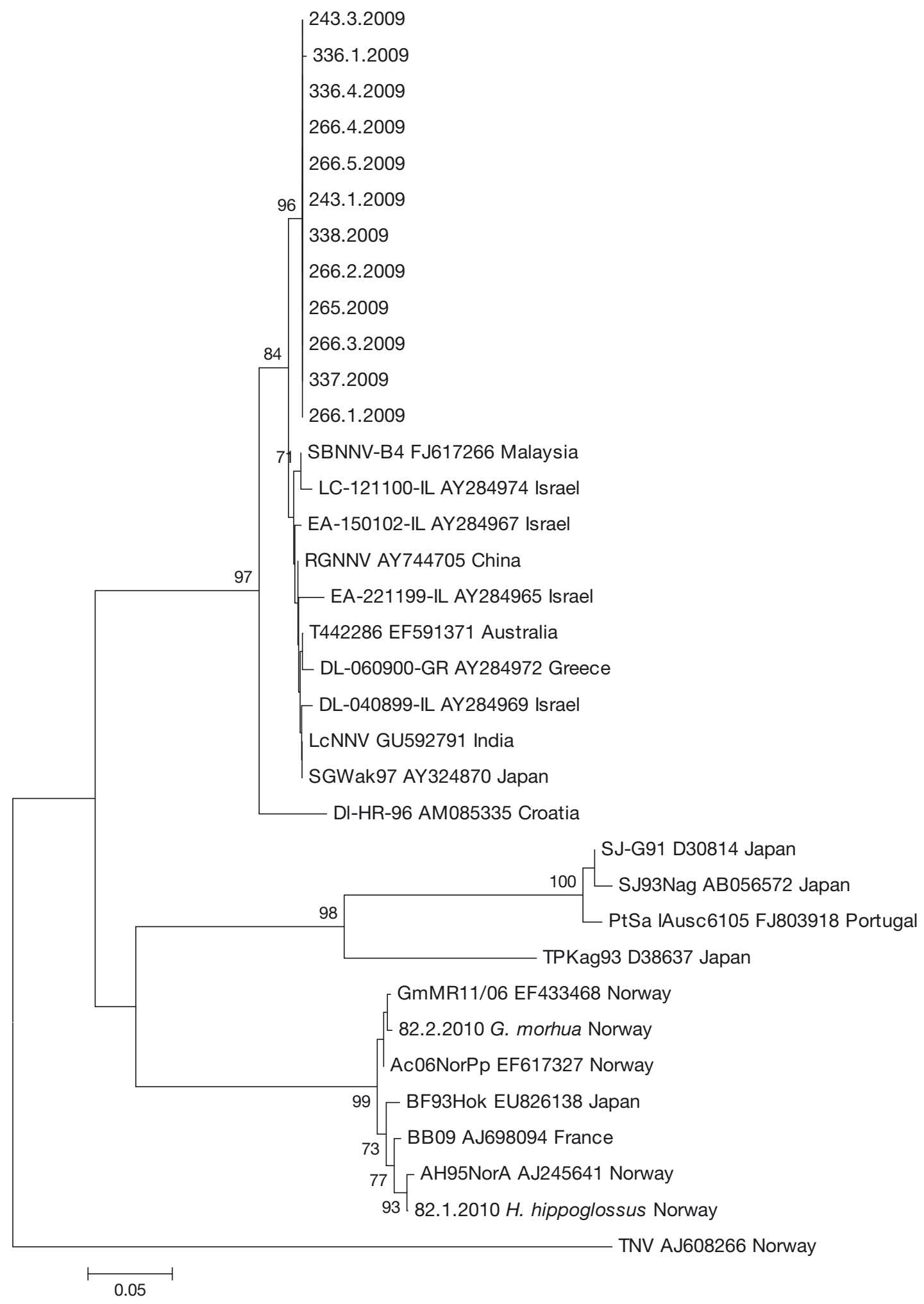

Fig. 3. Neighbour-joining (NJ) phylogenetic tree based on 489 bp nucleotide sequences of the RNA2 segment. Nodes are labelled with bootstrap values expressed as percentages. Only values $\geq 70$ are reported. The scale bar represents 0.05 nucleotide substitution per site 


\section{DISCUSSION}

Although the majority — and the most significantoutbreaks of VER are reported from species reared in the marine environment, there have been some reports of the disease in freshwater fish (Munday et al. 2002, Chi et al. 2003, Hegde et al. 2003, Athanassopoulou et al. 2004, Bigarré et al. 2009). In addition, several species of freshwater fish have been found to be susceptible to VER following experimental infection (Furusawa et al. 2007). These observations confirm that salinity is not a limiting factor, and they raise the possibility that other economically important freshwater fish may be susceptible to the disease.

In the present study, we investigated a natural outbreak of VER affecting largemouth bass Micropterus salmoides, pike-perch Sander lucioperca and hybrid striped bass (Morone saxatilis $\times$ Morone chrysops) reared in the same freshwater farm. During the outbreak, nodavirus was successfully isolated on SSN-1 cells and detected by IHC as well as by real-time PCR from several samples, collected on different occasions. The genetic characterization confirmed that the isolates obtained from the affected species belong to the RGNNV genotype, which is the most widespread in the Mediterranean region. The high-level similarity of both genomic segments (RNA1, RNA2) between the isolates studied indicates a single introduction of betanodavirus into the fish farm.

The first signs of the disease were detected in a population of 200000 hybrid striped bass, 0.1 to $0.2 \mathrm{~g}$ in size, $1 \mathrm{wk}$ after their introduction from Israel into what was previously considered a betanodavirus-free farm located in northern Italy. The early appearance of mortality among the hybrid bass after their arrival in the farm suggests that the origin of the infection is associated with the imported fish population. The high similarity observed between RNA2 sequences obtained in this study and Israeli sequences deposited in GenBank support our hypothesis and underline the high risk of disease transmission in the trade of live fish. To reduce this risk, trade in disinfected eggs - which are considered, with a few exceptions, as a safe commodity (OIE 2006) - should be encouraged.

Due to the lack of effective internal biosecurity measures, the infection spread very rapidly in the farm, affecting 2 further species farmed in different tanks. In particular, the infection was later detected in different batches of largemouth bass Micropterus salmoides and pike-perch Sander lucioperca, both developing typical clinical signs associated with significant mortality. No other species were present on the farm during the period of the clinical infection.

The cumulative mortality in the hybrid striped bass population was estimated at $20 \%$ based on the origi- nal population of 200000 fish, with maximum values close to the highest water temperature $\left(28\right.$ to $\left.30^{\circ} \mathrm{C}\right)$ observed during the outbreak. The largemouth bass population suffered a lower cumulative mortality of $10 \%$, while the pike-perch mortality rate was the lowest at $\sim 5 \%$ and ceased when the farmer lowered the water temperature to below $23^{\circ} \mathrm{C}$. The high temperature of the water during the mortality outbreak was probably a major factor in the clinical manifestation of the disease, generating a stressful condition for the fish.

Largemouth bass and pike-perch are important species for both sport fishing and farming purposes, and their susceptibility to VER represents a serious threat. In fact, both largemouth bass and pike-perch because of their wide distribution in both fresh and brackish waters - may be more likely to be exposed to VER from the marine environment. In the case described, only juveniles, aged $<3 \mathrm{mo}$, were affectedsuggesting that the clinical disease is age-dependent in these species too. This observation is in agreement with the majority of reports - with a few exceptions in which adults have been reported to be severely affected (Arimoto et al. 1993, Mushiake et al. 1994, Bovo et al. 1996, Fukuda et al. 1996, Le Breton et al. 1997, Nguyen et al. 1997, Tanaka et al. 1998, Aspehaug et al. 1999). In our case, largemouth bass over 3 mo (>1 g) recovered from clinical disease. Nevertheless, sampling carried out in the surviving population 3 mo after the appearance of the first clinical signs produced positive PCR reactions in 7 out of 10 fish collected from ongrowing ponds, and in 2 cases the virus was isolated (Table 3). This suggests that betanodavirus infection may persist in largemouth bass for several months without showing any clinical signs. This finding is not surprising given the fact that, in other species, such as the Atlantic halibut Hippoglossus hippoglossus, the presence of virus was detected several years after a natural outbreak (Aspehaug et al. 1999). Therefore, the surviving populations could harbour the virus for the rest of their lives and represent a risk, particularly during the reproductive season, given that vertical transmission of VER is suspected in a number of species (Arimoto et al. 1992, Mushiake et al. 1994, Breuil et al. 2002).

From the histopathological analysis, lesions of varying severity were observed, in both hybrid striped bass and largemouth bass, although in general the pathological changes in the nervous system and retina were found to be more significant in hybrid striped bass than in largemouth bass, in which only mild vacuolation within the retina was detected. No fixed tissues from pike-perch Sander lucioperca were available.

The identification of VER in these 3 species adds to the list of susceptible hosts and demonstrates that addi- 
tional susceptible species may be exposed to the virus as a consequence of inadequate biosecurity measures. VER is not included in any list of notifiable diseases either for the Office International des Epizooties (OIE) or European Union (EU) member states, and for this reason no surveillance programmes or control measures are officially adopted. As a consequence, there are no movement restrictions for this disease, and subclinically infected fish may be easily moved between different geographical areas, contributing to viral spread. In such situations economic losses due to outbreaks of disease may be resolved only by agreement between trade operators. The appearance of VER infection on the farm following the introduction of a population of hybrid bass from abroad underlines the high risk associated with the importation of fish populations in the absence of official health certification; it also stresses the importance of establishing strict biosecurity measures within farms, including quarantine. Furthermore, the spread of disease from hybrid bass to both largemouth bass and pike-perch represents another example of the risks associated with polyculture.

Further studies are necessary to clarify whether or not susceptibility to nodavirus infection in freshwater fish could be related to the salinity tolerance of some species of fish. Indeed, all the species reported as being naturally infected by nodavirus in freshwatersuch as tilapia, sturgeon, guppy (Hegde et al. 2003, Athanassopoulou et al. 2004, Bigarré et al. 2009) as well as hybrid striped bass, largemouth black bass and pike-perch in the present paper — seem to be highly tolerant to brackish waters (Chervinski 1984, Madsen et al. 1994, Cataldi et al. 1999, Jamil et al. 2004, Ložys 2004, Peer et al. 2006).

Acknowledgements. The authors thank M. Ferraresi (National Veterinary Service) and the owner of the infected farm for their collaboration and logistic support, W. Dundon for the careful and critical editing of the manuscript, and G. Cattoli for his valuable comments during the preparation of the manuscript.

\section{LITERATURE CITED}

Arimoto M, Mushiake K, Mizuta Y, Nakai T, Muroga K, Furusawa I (1992) Detection of striped jack nervous necrosis virus (SJNNV) by enzyme-linked immunosorbent assay (ELISA). Fish Pathol 27:191-195

Arimoto M, Mori K, Nakai T, Muroga K, Furusawa I (1993) Pathogenicity of the causative agent of viral nervous necrosis disease in striped jack, Pseudocaranx dentex (Blochand Schneider). J Fish Dis 16:461-469

Aspehaug V, Devold M, Nylund A (1999) The phylogenetic relationship of nervous necrosis virus from halibut (Hippoglossus hippoglossus). Bull Eur Assoc Fish Pathol 19: 196-202
Athanassopoulou F, Billinis C, Prapas Th (2004) Important disease conditions of newly cultured species in intensive freshwater farms in Greece: first incidence of nodavirus infection in Acipenser sp. Dis Aquat Org 60:247-252

Bigarré L, Cabon J, Baud M, Heimann M, Body A, Lieffrig F, Castric J (2009) Outbreak of betanodavirus infection in tilapia, Oreochromis niloticus (L) in fresh water. J Fish Dis 32:667-673

Bovo G, Borghesan F, Mutinelli F, Montesi F, Comuzzi M (1996) Viral encephalo-retinopathy of reared sea bass: first detection in Italy. Boll Soc Ital Patol Ittica 19:52-64

Breuil G, Pepin JF, Boscher S, Thiéry R (2002) Experimental vertical transmission of nodavirus from broodfish to eggs and larvae of the sea bass, Dicentrarchus labrax (L.). J Fish Dis 25:697-702

Cataldi E, Barzaghi C, Di Marco P, Boglione C and others (1999) Some aspects of osmotic and ionic regulation in Adriatic sturgeon Acipenser naccarii. I: Ontogenesis of salinity tolerance. J Appl Ichthyol 15:57-60

Chervinski J (1984) Salinity tolerance of the guppy, Poecilia reticulata Peters. J Fish Biol 24:449-452

Chi SC, Shieh JR, Lin SJ (2003) Genetic and antigenic analysis of betanodaviruses isolated from aquatic organisms in Taiwan. Dis Aquat Org 55:221-228

Fukuda Y, Nguyen HD, Furuhashi M, Nakai T (1996) Mass mortality of cultured seven band grouper, Epinephelus septemfasciatus, associated with viral nervous necrosis. Fish Pathol 31:165-170

Furusawa R, Okinaka Y, Uematsu K, Nakai T (2007) Screening of freshwater fish species for their susceptibility to a betanodavirus. Dis Aquat Org 77:119-125

> Hegde A, Teh HC, Lam TJ, Sin YM (2003) Nodavirus infection in freshwater ornamental fish, guppy, Poecilia reticulatacomparative characterization and pathogenicity studies. Arch Virol 148:575-586

Jamil K, Shoaib M, Ameer F, Lin H (2004) Salinity tolerance and growth response of juvenile Oreochromis mossambicus at different salinity levels. J Ocean Univ China 3: 53-55

Johansen R, Sommerset I, Tørud B, Korsnes K and others (2004) Characterization of nodavirus and viral encephalopathy and retinopathy in farmed turbot, Scophthalmus maximus (L.). J Fish Dis 27:591-601

Le Breton A, Grisez L, Sweetman J, Ollevier F (1997) Viral nervous necrosis (VNN) associated with mass mortalities in cage-reared sea bass, Dicentrarchus labrax (L.). J Fish Dis 20:145-151

Ložys L (2004) The growth of pikeperch (Sander lucioperca L.) and perch (Perca fluviatilis L.) under different water temperature and salinity conditions in the Curonian Lagoon and Lithuanian coastal waters of the Baltic Sea. Hydrobiologia 514:105-113

> Madsen SS, McCormick SD, Young G, Endersen JS, Nishioka RS, Bern HA (1994) Physiology of seawater acclimation in the striped bass, Morone saxatilis (Walbaum). Fish Physiol Biochem 13:1-11

Maltese C, Bovo G (2007) Viral encephalopathy and retinopathy. Ittiopatologia 4:93-114

> Munday BL, Langdon JS, Hyatt A Humphrey JD (1992) Mass mortality associated with a viral-induced vacuolating encephalopathy and retinopathy of larval and juvenile barramundi, Lates calcarifer (Bloch). Aquaculture 103: $197-211$

> Munday BL, Kwang J, Moody N (2002) Betanodavirus infections of teleost fish: a review. J Fish Dis 25:127-142

Mushiake K, Nishizawa T, Nakai T, Furusawa I, Muroga K (1994) Control of VNN in striped jack: selection of spawn- 
ers based on the detection of SJNNV gene by polymerase chain reaction (PCR). Fish Pathol 29:177-182

Mutinelli F, Bozza MA, Basilicata L, Bovo G (1998) Diagnosi istologica ed immunoistochimica della Encefaloretinopatia virale della spigola di allevamento (Dicentrarchus labrax). Boll Soc It Patol Ittica 23:1-10

Nguyen HD, Mushiake K, Nakai T, Muroga K (1997) Tissue distribution of striped jack nervous necrosis virus (SJNNV) in adult striped jack. Dis Aquat Org 28:87-91

Nishizawa T, Furuhashi M, Nagai T, Nakai T, Muroga K (1997) Genomic classification of fish nodaviruses by molecular phylogenetic analysis of the coat protein gene. Appl Environ Microbiol 63:1633-1636

OIE (Office International des Epizooties) (2006) Viral encephalopathy and retinopathy. In: Manual of diagnostic tests for aquatic animals. OIE, Paris, p 169-175

Panzarin V, Patarnello P, Mori A, Rampazzo E, Cappellozza E, Bovo G, Cattoli G (2010) Development and validation of a real-time TaqMan PCR assay for the detection of betanodavirus in clinical specimens. Arch Virol 155: 1193-1203

Peer AC, DeVries DR, Wright RA (2006) First-year growth and recruitment of coastal largemouth bass (Micropterus salmoides): spatial patterns unresolved by critical periods

Editorial responsibility: Mark Crane, Geelong, Victoria, Australia along a salinity gradient. Can J Fish Aquat Sci 63: 1911-1924

Schneemann A, Ball LA, Delsert C, Johnson JE, Nishizawa T (2005). Family Nodaviridae. In: Fauquet CM, Mayo MA, Maniloff J, Desselberger U, Ball LA (eds) Virus taxonomy. Eighth report of the international committee on the taxonomy of viruses. Academic Press, New York, NY, p 865-872

Skliris GP, Richards RH (1999) Nodavirus isolated from experimentally infected tilapia, Oreochromis mossambicus (Peters). J Fish Dis 22:315-318

Tamura K, Dudley J, Nei M, Kumar S (2007) MEGA4: molecular evolutionary genetics analysis (MEGA) software version 4.0. Mol Biol Evol 24:1596-1599

Tanaka S, Aoki H, Nakai T (1998) Pathogenicity of the Nodavirus detected from diseased seven band grouper Epinephelus septemfasciatus. Fish Pathol 33:31-36

Toffolo V, Negrisolo E, Maltese C, Bovo G, Belvedere P, Colombo L, Valle LD (2007) Phylogeny of betanodaviruses and molecular evolution of their RNA polymerase and coat proteins. Mol Phylogenet Evol 43:298-308

- Yoshikoshi K, Inoue K (1990) Viral nervous necrosis in hatchery-reared larvae and juveniles of Japanese parrotfish, Oplegnathus fasciatus (Temminck \& Schlegel). J Fish Dis 13:69-77

Submitted: December 13, 2010; Accepted: April 11, 2011 Proofs received from author(s): July 1, 2011 